\title{
The Legal Paradigm in a Global Context: Judicial of Evidence in Actualization of Electronic in Indonesia.
}

\author{
Finna Nazran ${ }^{1}{ }^{*}$ Tan Kamello ${ }^{2}$, Hasim Purba ${ }^{3}$, Saidin $^{4}$ \\ Universitas Sumatera Utara-Indonesia ${ }^{1234}$ \\ Email: finnanazran@gmail.com
}

\begin{abstract}
Development in a time of globalization has brought an electronic movement, including the development of electronic evidence. According to Indonesian procedural law, electronic evidence is an extension of legal evidence.This paper discusses the development and comparison of law in a global context, the development of the evidence system and evidence in the judiciary in Indonesia, as well as the actualization of electronic evidence in the judiciary system in Indonesia. The problem in this paper is how to actualize electronic evidence in the judiciary system in Indonesia. This papers is normative legal research using a descriptive analytical method which aims to explain, describe and correlate legal regulations and theories with the problems that occur. The finding shows that the actualization of electronic evidence in the judiciary system in Indonesia can be stated that electronic evidence has the status as a substitute for letters or independent evidence and can be used as a legal basis for judges to determine decisions. Electronic evidence that can be used to prove a criminal act in court must meet the requirements for its validity, namely that It may be accessible, presented, guaranteed, and accounted for, thus it should be considered.
\end{abstract}

Keywords: Civil Court, Electronic Evidence, Globalization.

\section{INTRODUCTION}

The development Information technology will eventually of Finally, necessitates the use of information technology by judicial authorities in numerous nations, including Indonesia. Development in a time of globalization has brought an electronic movement, including the development of electronic evidence which impacts on the judiciary system in Indonesia. The dynamics of globalization with all its dimensions will have an influence on the development of national law.

The laws and regulations in Indonesia explicitly regulate evidence obtained electronically Law Number 19 of 2016 amending Law Number 11 of 2008 respecting Information and Electronic Transactions (UU ITE) establishes a legislative foundation for the legal strength of electronic evidence as well as the formal and material conditions for electronic evidence to be admitted in court. Along with the growth of information technology, recognition of electronic data has become an intriguing subject (internet). Several nations, including Australia, Chile, China, Japan, and Singapore, have legislative provisions that allow electronic data to be used as legal evidence in court.

The ITE Law stipulates that Electronic Documents and/or Electronic Information [1] and/or the printout is admissible in court. The electronic evidence is a type of judicial evidence that extends beyond the courtroom in accordance with the applicable procedural law in Indonesia.[2] As for what is meant by expansion here, namely Adding evidence that has been regulated in Indonesian criminal procedural legislation, where electronic information and/or electronic documents as electronic evidence supplement the categories of evidence controlled specified by the Criminal Procedure Code in Indonesia.

After the issuance of the Constitutional Court Decision No. 20/PUU-XIV/2016 on 7 September 2016 which among other things states that the provisions regarding electronic evidence have a unique tool so that the evidence has a certain complexity that has an impact on the quality of evidence, so that in proving electronic evidence a special process is needed including in carrying out the authentication procedure electronic evidence.

\section{RESEARCH METHODS}

This papers is normative legal research[3]using secondary legal materials then connected in such a way to be able to answer the problems. 


\section{FINDING AND ANALYSIS}

\subsection{Legal Developments in a Global Context}

Upholding justice for all people is Indonesia's commitment as a state of law. Attempts to define what justice is, is not easy. Experts' interpretations are very diverse. Niels Anderson defines justice as the ideal in law by which judges are expected to be guided. Rudolph Helmanson defines justice as a concept to achieve a legitimate result to satisfy a proper demand, correct a mistake, find a fault, find a balance between legitimate but conflicting interests. Thomas Hoult defines justice as the principle of fair treatment and the practices and consequences associated with it.[4]

Within the framework of the 1945 Constitution, the legal objectives are formulated to safeguard the whole Indonesian nation and the entire Indonesian homeland, to achieve social justice for all Indonesians, and so on or in Jeremy Bentham's observation who holds the view of "the greatest happiness for the greatest number". This view asserts that the purpose of law is based on consideration of the greatest benefit for the people or maximizing benefits to promote the prosperity, welfare, and happiness of the community.[5]

Max Weber argues that decisions about legal issues are impacted by rules other than those derived from logical generalizations based on abstract meaning interpretations Ethical, practical, and prudent precepts, as well as political aphorisms, are all derived from formalism of the "external features" kind, as well as those employing logical abstraction, in the substantive rationality of law. However, in the contemporary sense, a highly unique professional, legalistic, and abstract approach to law is only feasible to the extent that the formality of the law. [6]

The existence of the discourse of globalization has reminded the old conflict about what happens when the law is grafted from one place to another. Is the latest wave of globalization just an iterative version of the previous colonial domination to date, then with the packaging of attractive trade deals and development programs, forcing middle class families to comply with metropolitan standards? Colonialism itself is not primarily focused on legal transplantation.[7]

Globalization also creates a process of deterritorialization or a spread of supraterritoriality, namely the emergence of regulations or institutions that go beyond the territoriality of the nation state. The national space is no longer seen as a relevant space for decision making because more and more issues must be resolved at a higher level such as regional or global.[8] The reality of globalization has influenced the course of legal history. Law is no longer a collection of original regulations from local and national communalities, but has been influenced by global values which are reflected in relations and communication and boundaries between people through access provided by global communication technology products, namely the internet. [9]

In the context of Indonesia, the struggle to uphold the principle of a fair trial has long begun. The legal system has certain goals and objectives. The objectives and targets of the law can be in the form of people who actually act against the law, also in the form of the legal act itself, and even in the form of state apparatus or apparatus as law enforcers. The legal system has a certain mechanism that guarantees the implementation of the rules in a fair, definite and firm manner, and has benefits for the realization of public order and peace. The working system of the law is a form of law enforcement.

Classifying the world's legal systems into the three main legal families or legal traditions has become a generally recognized practice. The three Civil law, common law, and socialist law are the three types of legal families.[10] Legal tradition is defined historically to the essence of law, the rule of law in society, and political philosophy, as well as the legal system's organization and application. At the beginning of the 20th century there was a wave of opinions in favor of the spread of comparative studies, and in 1990 the concept of family law was introduced into comparative law. The main objective of comparative studies is to secure the unification of the whole or at least a substantial part of all legal systems that exist in civilized societies in the world. [11]

Law is essentially a certain structure that gives shape to human goals that move humans to act. In order to find general principles for the formation of such a structure, it must be abstracted from these goals from real social life. Then with a logical analysis, we will find certain principles of legal organization (juridical organization) that are absolutely legitimate and will guide us safely in making judgments about which goals are worthy of recognition by law and how these goals are related. each other legally (jurally related). [12]

4. The System of Evidence and the Form of Evidence in the Judiciary in Indonesia

The system adopted by the Criminal Procedure Code is a negative evidence system according to the law in which it reads "a judge may not impose a crime on individual unless he gets confidence from at least two legitimate forms of evidence that a criminal conduct has happened and the defendant is guilty of doing it."In other words, to impose a sentence on the defendant, two valid in the form of evidence must be met and the judge believes this crimes has been committed and that the criminal is guilty or accused is responsible for it. [13]

Positive Legal Evidence (positive wettelijke bewijstheorie) furthermore, the evidence system is guided by the principle of evidence using the form of evidence determined by the law. The judge's belief is set aside in this system. In proving the defendant's guilt as 
long as the terms and conditions of proof according to the law have been fulfilled, it is sufficient to determine the guilt defendant without questioning whether the judge believes or not. If proven legally according to the law, the judge can sentence the defendant. The goodness of this proof system is that in determining the proof of the defendant's guilt, the judge is required to seek and find the truth of whether or not the defendant is in accordance with the procedure for proving with the evidence that has been determined by law.

While Negative Legal evidence (Negatif Wettelijke Bewijstheorie) is a combined by the evidence system of a positive evidence system according to the law and a evidence system according to the judge's conviction. So this evidence system is a balance between two systems that contradict each other. So it can be concluded that if the A defendant's conduct is judged by a judge's conviction. based on methods and with legal form of evidence according to the law by means of proof, then it must be carried out according to the method and with legal form of evidence according to law Legal beliefs that must also be based on methods and with legal evidence according to the law.

Evidence was made by the judge's reasonable reasoning (conviction rationale) This theory is nearly identical to the idea of Conviction in Time, namely evidence based on the judge's belief, but it is constrained by clear reasons, where the judge must describe and explain the grounds underpinning the defendant's guilt conviction.. The reasons in question must be accepted with common sense. Judges are not bound by the the form of evidence applied by law. Thus the judge can use other form of evidence that is outside the statutory provisions. [14]

There are various forms of evidence, it really depends on how a legal expert gives definitions to each of these evidences. Legal experts will provide a definition of course by first defining the meaning of a proof..[15] Subekti argues that proving is an attempt to persuade the court of the reality of the case arguments put forward in a dispute.[16] Sudikno Mertokusumo has a different opinion, namely, what is referred to in the juridical sense from the context of evidence is an attempt to offer adequate grounds for judges to investigate it cases in order to establish clarity regarding the reality of the legal events presented..[17]

The development of science and technology will directly affect the development of existing the form of the evidence. This is related to the use of science and technology in society, and more specifically by criminals, it is even used as a means to uncover crimes by law enforcers. The judiciary system in each country is influenced by the legal system adopted by that country. The Indonesian Justice System can be interpreted as "an orderly and interconnected structure, which relates to the activities of examining and deciding cases carried out by the courts, be it courts within the general judiciary, religious courts, military courts, or state administrative courts," according to Indonesian attitudes, philosophies, and principles in the realm of justice.

In the process of examination in a criminal court, evidence is very important to be presented, because someone is found guilty or not depends on the evidence presented in the trial. Proof is the act of proving. To prove means to give or show evidence, to do something true, to carry out, to signify witness and to convince. So in connection with this, the precautionary principle is very important to be applied in assessing the evidence. Determination of a person's guilt or innocence is determined by the evidence. If the evidence presented before the court is not sufficient to prove a person guilty, it will be released from punishment, but this is reversed if the evidence presented is able to prove the person is guilty and get sentenced in conformity with the legislation in force

\subsection{Actualization of Electronic Evidence in the Justice System in Indonesia}

Before the enactment of the ITE Law, Indonesia in the legal system of evidence related to problems with electronic evidence has not been clearly regulated. The presence by the ITE's Electronic evidence serves as information, electronic documents, and printouts, according to the law. that have legal force as evidence in court. . Thus, this law is expected to "respond to various rights related to law (including the law of evidence) relating to cyberspace (cyber law, virtual world law), technology and communication law (law technology of information and communication), and the law on commerce using electronics (e-commerce).[18]

Based on Article 44 of the ITE Law, In addition to the evidence, electronic evidence in the form of information and/or electronic documents is another type of evidence. As referred to in the statutory provisions for the purposes of investigation, prosecution and examination in court. In its original form, electronic documents are evidence other than the evidence The Criminal Procedure Code regulates this. The ITE Law also establishes the conditions under which electronic evidence can be considered valid, namely the formal requirements set forth in Article 5 paragraph (4) of the ITE Law, which state that the provisions on electronic information and documents in Article 5 paragraph (1) do not apply to letters, which must be written and in the form of a notarial deed.

Meanwhile, Article 6 of the ITE Law regulates the material requirements, which require that information be in written or original form. If the information mentioned is available, shown, its integrity is ensured, and can be accounted for in order to explain a situation, it is deemed legitimate electronic information and/or electronic documents. Electronic evidence, according to the ITE Law, is an extension of the evidence governed by the Criminal Procedure Code. According to Article 
187 letter $\mathrm{d}$ of the Criminal Procedure Code, printed findings from electronic documents might be classified as other letters. [19]

The Civil Code has determined that the evidence in civil procedural law, if sorted based on the strength of the evidence, consists of (a) written evidence, both authentically and underhand; (b) witnesses; (c) suspicion; (d) recognation; (e) oath.[20] If further analyzed, the agreement or contract is included in the classification of written evidence as long as the document meets the requirements to be declared a valid Article 1320 of the Civil Code requires an agreemen.

Edmon Makarim argued that the principle of functional equivalent (functional equivalent approach) that must be met with a minimum of 3 (three) basics so that information and electronic documents can be said to be the same as written evidence, namely "can be stored and recovered, the substance has not changed or its authenticity is guaranteed." , and sign if there is evidence explaining the existence of a legal object that is accountable for it, or if there is a trustworthy authentication method explaining that party's identity, authorization, or verification."." [21]

Referring to Electronic evidence is regarded legitimate as evidence for establishing a crime if it employs a specified electronic system and can be accessible, shown, and its integrity is assured AND accounted for, according to Article 5 paragraph (3) and paragraph (4) of Law No. 11 of 2008 and its explanations. If electronic evidence has met the requirements of being reliable, credible, relevant, and material, it must be accepted by the court as legal evidence in criminal procedural law for proving criminal acts in court.[22]

The power of proof of this electronic Letter evidence and directive evidence are two types of evidence that might be used. The Criminal Procedure Code regulates electronic evidence as an extension of physical evidence. namely letter evidence and evidence of instructions. As has been explained, the Criminal Procedure Code as the main (general) criminal procedural law applicable in Indonesia strictly does not include electronic evidence in the types of evidence. Provisions regarding electronic evidence are contained in several special laws, such as criminal acts of terrorism, criminal acts concerning the use of data and transactions Electronc, narcotics crimes, and so on. When a crime is regulated in a special law, electronic evidence can be used for proof in court of law, although It is not governed by the Criminal Procedure Code. In this case the principle applies or the principle of "lex specialist derograt lex generalist" (special criminal laws override general laws). Electronic evidence can only be used to prove a specific crime in accordance with the laws that govern it. [23]

Despite the fact regardless that electronic evidence is not explicitly controlled in criminal procedural law, it is founded on the judicial premise that courts cannot refuse to study and determine cases even if the legal justification is ambiguous or non-existent, as well as the idea that judges must explore legal values as society grows and develops. The ITE Law, which has regulated electronic evidence as legal evidence, can be used as a basis for making electronic evidence. [24]

In conformity with the ideals of justice as enshrined outline, regulated in Article 5 paragraph (1) Jo. Article 10 paragraph (1) of the Republic of Indonesia Law Number 48 of 2009 concerning Judicial Power in Indonesia, the functions of judges in enforcing the law is to make legal discoveries (rechtsvinding). With the function of the judge, the applicable law Indonesia follows an open system. That is, written law is open to input from other non-legal factors. Thus, the actualization of electronic evidence in the judicial system in Indonesia can be stated that electronic evidence has the status as a substitute for letters or independent evidence which can then be used as the basis for judges to obtain instructions.

\section{CONCLUSION}

To be able to keep up with existing technological developments, the judicial system in Indonesia requires procedural law that can clearly and firmly regulate the application of electronic evidence so that it is hoped that the validity of electronic evidence will no longer be a debate. Electronic documents and their printouts have legal force as evidence in court of law. The power of proof of this electronic evidence can use the power of proof of letter evidence and directive evidence. The Criminal Procedure Code regulates electronic evidence as an extension of evidence, namely letter evidence and evidence of instructions. Electronic evidence that can be used to prove a crime in court must meet the requirements for its validity, namely that It has the ability to be accessible, exhibited, guaranteed, and accounted for in order to explain a situation connected to a crime that occurred.

\section{ACKNOWLEDGMENT}

The author would like to thank you profusely for all the help that has been given, either directly or indirectly during the preparation of this research complete Properly. In particular, gratitudes that are due to Doctoral Program in Law, University of North Sumatra, which has supported the author, so that this research can be published in international journals.

\section{REFERENCES}

[1] Article 1 paragraph 1 in conjunction with Article 1 paragraph 4 of Law Number 19 of 2016 concerning Amendments to Law 11 of 2008 , concerning Information and Electronic Transactions 
[2] Article 5 paragraphs 1 and 2 of Law Number 11 of 2008concerning Information and Electronic Transactions

[3] Soemitro, R.,H1988,Metodologi Penelitian Hukum dan Jurimetri, Jakarta, Ghalia Indonesia, , p. 1314.

[4] Surajiyo, 2018,Keadilan Dalam Sistem Hukum Pancasila, IKRAITH-humanira Vol 2 No 3 Bulan November, hal. 22

[5] Bentham,J.,2000,An Introduction to the Principle of Moral and Legislation, (Batoche Book, Kitchener,), p. 6

[6] RheinsteinM.,1995,Max Weber on Law in Economy and Society, artikel dalam Stewart Macaulay, Lawrence M. Friedman, John Stookey, Law and Society : Readings On The Social Study Of Law, New York, London : W.W Norton \& Company, , p. $185-207$

[7] MenskiW.,2016,Perbandingan Hukum dalam Konsteks Global, Sistem Eropa, Asia dan Afrika, Bandung, Nusa Media, , p.47

[8] AgusR., 2016,Sejarah Hukum, Karanganyar, Oase Pustaka, , p.63

[9] Ib id

[10 ]CruzP.d, 2016,Perbandingan Sistem Hukum, Common Law, Civil Law dan Socialist Law, Nusa Media, Bandung bekerja sama dengan Diadit, Jakarta, p.46

[11] I b id, p. 48

[12] RahardjoS.2000,Ilmu Hukum, Bandung: Citra Aditya Bakti, cet. V.., p. 263

[13] See Article 183 of the Criminal Procedure Code

[14]https://www.pnlhoksukon.go.id/content/artikel/2017 061413092611035007145940d3161beaa.html, accessed on March 5, 2021, 19:42 WIB

[15] ImronA.\&IqbalM.,, 2019,Hukum Pembuktian, Tangerang Selatan,UNPAM PRESS, , p.2

[16] Subekti, 2001,Hukum Pembuktian, Jakarta, Pradnya Paramitha, , p 1.

[17] MertokusumoS., 2006,Hukum Acara Perdata Indonesia, Yogyakarta, Liberty, , hal. 135

[18] FuadyM, 2012,Teori Hukum Pembuktian Pidana dan Perdata, Bandung, Citra Aditya Bakti, , p. 168.

[19] DewiK.A.T.C, \&AdiyaryaniN.N, 2019, 'Kedudukan Alat Bukti Elektronik Dalam Hukum Acara Pidana Indonesia', Jurnal Kertha Wicara, Vol 8 No. 7, p.11

[20] See Article 1866 of the Civil Code

[21]Makarim E.,2015, 'Keautentikan Dokumen Publik Elektronik Dalam Administrasi Pemerintahan Dan Pemerintahan Publik',Jurnal Hukum dan Pembangunan, No. 4 p. 532.

[22] Ramiyanto, 2017,'Bukti Elektronik Sebagai Alat Bukti Yang Sah Dalam Hukum Acara Pidana', Jurnal Hukum dan Peradilan, Vol. 6 No. 3, November, p.469

[23] I b id, p. 476

[24] I b id, p. 480 